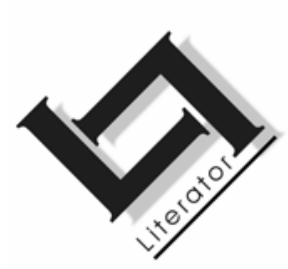

\title{
Die digter in transito: reisverse en liminaliteit in Lykdigte en Ruggespraak van Joan Hambidge
}

\author{
dit was my bestemming \\ en hierin lê die reis van my begeerte \\ Pablo Neruda
}

Adéle Nel

Skool vir Tale

Vaaldriehoekkampus

Noordwes-Universiteit

VANDERBIJLPARK

E-pos: Adele.Nel@nwu.ac.za

\begin{abstract}
The poet in transit: travel poetry and liminality in Joan Hambidge's Lykdigte and Ruggespraak

In the poem "Versugting" the first person narrator confesses: "reis na reis het ek in gedigte gekarteer, / in woorde opgevang elke slopende liefdeservaring". The most important themes in Hambidge's poetry converge in these two lines, namely the travel experience, reflection on the writing process, and love. These themes are the focus of this article. In both volumes under discussion the poet is presented as a traveller in real life. This concrete experience of reality becomes the isolated journey of the psyche and is "translated" and mapped in verse form. The journey as a liminal experience, the poet as the traveller and the writing process as the journey are some of the aspects that will be examined. For the poet the travel experience also implies the search for the beloved/love/the poem, while the transferral of the self causes a feeling of displacement. The city as destination also plays a role in the travel experience, which is experienced in a spatial-poetic manner, and finally becomes a poem itself.
\end{abstract}




\section{Opsomming}

\section{Die digter in transito: reisverse en liminaliteit in Lykdigte en Ruggespraak van Joan Hambidge}

In die gedig "Versugting" bely die skrywende ek: "reis na reis het ek in gedigte gekarteer, / in woorde opgevang elke slopende liefdeservaring". In hierdie twee versreëls word die belangrikste temas in Hambidge se digkuns ondervang, naamlik die reiservaring, die refleksie op die skryfproses en die liefde. Hierdie temas is die fokus van hierdie artikel. In albei die bundels onder bespreking word die digter as reisiger in die werklike lewe voorgehou. Die konkrete werklikheidservaring word 'n alleenreis van die psige en word "vertaal" en gekarteer in versvorm. Die reis as liminale ervaring, die digter as reisiger en die skryfproses as reis, is aspekte wat onder andere ondersoek word. Vir die digter impliseer die reiservaring ook 'n soektog na die geliefde/liefde/die gedig, terwyl die verplasing van die self 'n gevoel van ontheemding tot gevolg het. Die stad as bestemming speel ook 'n rol in die reiservaring en word ruimtelik-poëties ervaar, maar word uiteindelik self ook'n gedig.

\section{Inleiding}

In die gedig "Versugting" (Hambidge, 2000:41) bely die skrywende ek: "reis na reis het ek in gedigte gekarteer, / in woorde opgevang elke slopende liefdeservaring". In hierdie twee versreëls word die belangrikste temas in Hambidge se digkuns ondervang, naamlik die reiservaring, die refleksie op die skryfproses en die liefde. Daar word terselfdertyd ook 'n besliste verband tussen ruimte (konkreet en abstrak) en die digterlike proses gelê. Hierdie temas kan as liminaal beskryf word, omdat daar in elkeen by implikasie 'n drempel tussen die konkrete of reële ervaring en die innerlike of metafisiese ervaring, of tussen ervaring en abstrakte woord, ingebed is. Hambidge (2002b) se verseksterne uitspraak kan in hierdie verband aangehaal word, as sy die skryfproses as argitektoniese konstruksie verduidelik:

[V]ir die digter begin hierdie argitektoniese proses wanneer iets in die werklike lewe waargeneem, in 'n gedig vasgelê word. lets uit die konkrete werklikheid word 'vertaal' in versvorm. Hierdie proses is ' $n$ ingewikkelde een wat dikwels op my vele reise in die buiteland ontstaan het.

Snyman (1998:510-511) wys in die profiel oor Hambidge in Perspektief en profiel op enkele belangrike fasette van Hambidge se digkuns wat by die lees daarvan in gedagte gehou moet word. Hy maak onder andere die stelling dat Hambidge by uitnemendheid ' $n$ 
simbole-digter is, en hy toon ook Hambidge se obsessie met die woord aan:

'n Groot deel van hierdie digteres se werk is 'n ondersoek na die moontlikhede van die woord: die lyflikheid daarvan, die potensiaal daarvan as teken, die beskerming wat dit bied én die blootstelling, en die simboliese krag wat die mistieke element ingesluit hou. [...] Want die simbool weerspreek die logos, dit abstraheer die 'realiteit van die woord' en dit bevry die woord van sy betekenis. Die simbool is die oorgang tot die primordiale wêreld, dit is die ritueel van taal. Hambidge se poësie benut hierdie teenstelling van logos teenoor simbool om enersyds die aktuele en die poësie in 'n een:een-verhouding te kry, en andersyds om die mens (persoon) met sy brutale menslikheid te herlei tot die primitiewe wêreld van die psige met sy onderbewuste en duister skoonheid (kursivering - AN).

Die proses wat Snyman hier beskryf, die oorgang en die ritueel het óók betrekking op liminaliteit. Vir Aguirre et al. (2000:6) is 'n limen 'n drempel tussen twee ruimtes; 'n opening wat deurgang van die een ruimte na die ander bied. Hulle definieer liminaliteit formeel soos volg:

A definition of liminality invites or requires the postulation of an open, plural system the constituents of which include a known area $A$ and, at least, a poorly understood area B, plus a recognition of a threshold separating but also relating $A$ and $B$, the threshold itself having a variable breadth. By "liminal" we will understand texts or representations generated between two or more discourses, a transition area between two or more universes which thereby shares in two or more poetics. In a second sense, we will also apply the term "liminal" to texts, genres or representations centred around the notion of the threshold, or whose fundamental theme is the idea of a crossover, a transgression or an entry into the Other.

Smith (2004:49) se opvatting oor die drempelervaring as tussentoestand of as liminale ruimte kan in hierdie verband ter stawing aangehaal word:

A threshold is something which is fundamental to the construction of 'meaning' through the existence of difference. It marks a passage from one state to another. In psychoanalytic terms, thresholds define the very process of subjectivity and of meaning" (kursivering - AN).

'n Drempel is dus 'n oorgang, 'n grens wat oorgesteek word om van een ruimte na ' $\mathrm{n}$ ander te beweeg, hetsy in letterlike of figuurlike sin. 
Smith [2004:49] meen ook dat die grense van die drempel 'n problematiese begrip is, omdat die drempel 'n tussentoestand is wat deurdrenk is van ongelyke belangrikheid of betekenis. Juis omdat dit 'n oorgangsruimte of grens is, is dit as't ware 'n niemandsland wat nie aan die een of die ander kant behoort nie, maar op 'n paradoksale wyse is dit tog óók die terrein van albei kante - daar kan per slot van rekening geen drempel wees sonder 'n ruimte aan elke kant nie.

Hierdie ondersoek wil nagaan op watter wyse liminaliteit 'n rol speel in enkele gedigte in spesifiek Lykdigte (Hambidge, 2000) en Ruggespraak (Hambidge, 2002a). As vertrekpunte vir die betoog geld die volgende kwessies: Hambidge gebruik telkens liminale beelde om die temas van reis, die liefde en die digproses in haar digkuns te bevestig. In die gedig "E-Pos aan D.J. Opperman" (Hambidge, 2000:51) word die problematiek van die tussentoestand byvoorbeeld by implikasie verwoord:

Is dit waar dat as ' $\mathrm{n}$ mens reis na daardie plek (adres onbekend) of verhuis, jy tydelik vasgevang - soos in 'n gedig - bly, onwetend: dis alles onherroeplik verby?

Talle gedigte toon egter ook liminale eienskappe in sigself. In die gedig "Gebreekte sonnet" (Hambidge, 2002a:51) word die problematiek van die tussengebied in die gedig self byvoorbeeld eksplisiet uitgespel:

Wat gebeur tussen die oktaaf en sekstet?

Die sogenaamde "wit in die gedig"?

In geen handleiding, Ottone M. Riccio inkluis, vind ek enige aanwysing oor wat tussen droom en harde werklikheid gebeur.

Daar sal dus ondersoek ingestel word hoe hierdie fasette van liminaliteit in die gedigte aan die bod kom.

In 'n beduidende aantal gedigte in die Hambidge-oeuvre word daar 'n verband gelê tussen die reiservaring en die skryfproses, en/of die liefdeservaring en die skryfproses. Dit sluit by implikasie in die wyse waarop die gedig hom aan die digter opdring en die wyse waarop die digter die gedig opskryf, asook die motivering vir die dig-/ skryfambag; kortom, die ars poetica van 'n spesifieke digter soos wat dit in die gedigte self verklap word. Die vraag ontstaan ook watter rol die reiservaring en die metafore wat met reis verband hou in die 
poëtika van Joan Hambidge speel. Enkele van hierdie aspekte sal in oënskou geneem word.

\section{Reis as liminale ervaring}

Vir James Clifford in sy aantekeninge Notes on travel and theory (1989) is die term reis ' $n$ beeld vir die verskillende maniere van verblyf én verplasing, vir trajekte en identiteite, vir verhale wat vertel word en vir teoretisering in 'n postkoloniale wêreld met globale kontakte. Reis is voorts ook 'n reeks praktyke om die self voortdurend te verplaas in 'n ruimte of ruimtes wat te groot geword het - 'n vorm van sowel verkenning/ontdekking as dissipline. Uit die reiservaring kan 'n aantal vrae gekonstrueer word: Waarheen word gereis? Wat is die doel van die reis? Watter metafore word met reis in verband gebring? Watter soort kennis, verhale en teorieë word geproduseer? Volgens Clifford (1992:107) is die reisiger per definisie iemand wat die sekuriteit en die voorreg geniet om op relatief ongedwonge wyses te kan beweeg. Dit is in elk geval die mite van ons tyd. Een van die eienskappe van die hedendaagse reiskultuur word ook by implikasie deur Clifford (1992:109) uitgewys as hy die voortdurende dialektiek tussen tuiskoms en vertrek beklemtoon met die volgende stelling: "Everyone is more or less permanently in transit ... Not so much 'where are you from?' but 'where are you between?' (The intercultural identity question.)" (kursivering - AN). Said (1983:226-227) lê in sy essay Travelling theory 'n verband tussen reis en die sirkulasie van idees en kennis. Hy onderskei vier stadia van reis, naamlik 'n oorsprong, 'n afstand wat afgelê word, 'n stel voorwaardes vir aanvaarding of verwerping, en ten slotte 'n getransformeerde (geïnkorporeerde) idee wat ' $n$ nuwe posisie binne 'n nuwe tyd en ruimte okkupeer. Sowel Clifford as Said beklemtoon dus die plekbepaling ten opsigte van die nosie van reis, want elke reis begin en eindig immers êrens.

Vanweë die feit dat daar by die reiservaring die veronderstelling is dat grense oorgesteek word, sowel as van 'n transformasieproses, soos uit bogenoemde argumente blyk, kan die afleiding voorts gemaak word dat reis by uitstek 'n liminale ervaring is. Selfs in die roetine van reis is daar by implikasie ' $n$ rituele handeling ingebed. Tussen afskeid van die tuiste en tuiskoms bevind die reisiger hom/haar in die lughaweterminaal as (liminale) ruimte van vertrek, daarna in die vliegtuig as vervoertuig tussen herkoms en bestemming, en uiteindelik in die vreemde as verkenningsruimte. In dié proses word 'n aantal drempels of grense oorgesteek wat 'n ritueel van transformasie tot gevolg het as gevolg van 'n proses van 
(tydelike) ontheemding. Viljoen (2003:82) in navolging van Porter, wys daarop dat reis dikwels:

'n vorm van ondersoek is wat lei tot selfondersoek en selfontdekking. Die reis, sowel as die representasie daarvan in taal, is ook potensieel transgressief: die oorsteek van die letterlike grense tussen die bekende en die onbekende lei dikwels tot die oorsteek van 'n verskeidenheid ander grense.

Die hedendaagse reisiger wat stede en kontinente wil ontdek reis hoofsaaklik per vliegtuig, en in dié verband is die lughawe 'n belangrike oorgangsruimte van aankoms en vertrek. Chambers (1990:57) omskryf die liminale eienskappe van die moderne lughawe, wat hy ook bestempel as die miniatuurstede van ons tyd:

As a simulated metropolis it is inhabited by a community of modern nomads: a collective metaphor of cosmopolitan existence where the pleasure of travel is not only to arrive, but also not to be in any particular place ... to be simultaneously everywhere. This is a condition experienced not only by the contemporary traveller but also by many a contemporary western intellectual: the flâneur becomes a planeur.

\section{3. "In die aankoms- en vertreksaal van die poësie": die digter as reisiger}

Susan Sontag (2003:258) lê eksplisiet 'n verband tussen die reiservaring en skryf, sowel as tussen skryf en reis as geestelike ervaring, met die sentrale vraag: "What is a writer but a mental traveller?" Hierdie verband tussen skryf en reis, oftewel die digterlike ambag en reis word in die gedig "Ars poetica" (Hambidge, 2000:33) reeds deur die titel en aanvangsreël gereflekteer. Hambidge stel boonop die digter as reisiger onomwonde aan die bod:

Hoe dikwels het ek nie gereis,

my paspoort gestempel met noord, oos, wes en suid?

Uit die banale en gevaarlike, nie die verhewene, spruit poësie! Verrotting in Hong Kong,

' $n$ vlugvertraging in Dallas weens ' $n$ bom aan boord, of ' $n$ lugbesoedelde Santiago de Chile.

'n Gedig vergesel jou soos 'n vrypas;

is 'n diplomatieke vergunning: 'n paspoort

tot onnoembare, onherstelbare berou. 
Een van die opvallendste kenmerke van Hambidge se poësie is die feit dat sy telkens in die poësie besin oor die poësie. Daar is dus sprake van 'n eksplisiete versinterne poëtika. Hambidge se poëtika kan volgens Van den Akker (1985) se model in die eerste plek bestempel word as ' $n$ ekspressiewe literatuuropvatting, naamlik waar die verhouding teks-digter die belangrikste is. Snyman (1998:504) staaf hierdie stelling, want hy bestempel Hambidge se poësie as ' $n$ "epos van die psige" waarin die "intieme wêreld van die gees" verken word. Crous (2000:8) is egter óók in die kol as hy die stelling maak dat die obsessie met die woord sentraal binne haar oeuvre is, asook 'n besinning oor die digter se worsteling met die woord wat noodwendig lei tot selfkennis. Daar is dus in die tweede plek sprake van 'n outonomistiese literatuuropvatting waarin die verhouding tekssigself oorheers. In dié poësie is die poësiekonsepsie dikwels die onderwerp van die gedig self, en hierdie selfbewuste digterskap impliseer 'n bewustelike omgaan met die ontstaanswyse van die gedig, die inherente probleme of moontlikhede van die kreatiewe proses, en die verband tussen die gedig as taalmaaksel en die werklikheid waaruit dit gekonsipieer word.

Die reiskode staan inderdaad sentraal in Hambidge se oeuvre, want deur die reiservaring ervaar die digter/spreker verskeie modusse van bestaan. In talle bundels word die digter as reisiger voorgehou wat verskeie geografiese terreine in die wêreld verken. Hierdie konkrete werklikheidservaring word egter terselfdertyd 'n interne reis, of wat Hambidge (2002b) in 'n verseksterne uitspraak "n alleenreis van die psige" noem. Versintern verwoord sy in die gedig "In transit" (Hambidge, 1988:25) soos volg:

Want meer word bereis

as 'n land en sy mense -

'n innerlike landskap verken

soos miere grawend

in los tonnels.

In 'n onderhoud met Hanlie Retief (2003:25) voer Hambidge aan dat reis die sentrale metafoor van haar lewe geword het. "Dis wonderlik om die wêreld te sien, maar daar's ook die innerlike reis, om tot 'n soort persoonlike klaarheid te kom." Edmund Husserl (soos aangehaal deur Kickasola, 2004:30) se opvatting is veral ook relevant in hierdie verband. Hy het geglo dat werklike betekenis nie in die verstand alleen, of in die wêreld alleen gesetel is nie, maar in die opsetlike verhouding tussen die twee. Die konkrete, sowel as interne reiservaring, word dus deur die digter met betekenis gelaai, "vertaal" en gekarteer in versvorm. Die topografie van die vreemde 
determineer met ander woorde die topografie van die gees en albei manifesteer in die taalhandeling. Hambidge (2002b) verduidelik soos volg:

Die gedig stol, behou en vries emosies. En hoe verder'n mens reis in 'n nuwe, onbekende landskap in, des te meer raak jy bewus van die hartlandskap van jou taal. Miskien hierom het die meeste van my bundels in 'n vreemde land ontstaan: Hartskrif aan die Oos-Kus van Amerika; Ruggespraak in New York en Japan; Geslote baan in die Skandinawiese lande ... Juis binne 'n vreemde omgewing raak ek altyd bewus van die mag wat Afrikaans oor my het.

\subsection{Die skryfproses as reis}

Dit is egter nie net die digter wat as reisiger getipeer word nie, maar die skryfproses self word ook as 'n reis uitgebeeld. Ter stawing kan Chambers (1994:10-11) in dié verband aangehaal word:

... for to write is, of course, to travel. It is to enter a space, a zone, a territory ... The point of the author, the point of arrival, becomes the point of departure, and the boundary of the sentence is breached by the surplus of language. In this manner writing can become a travelogue, a constant journeying across the threshold between event and narration, between authority and dispersal, between repression and representation, between the powerless and power, between anonymous pretext and accredited textual inscription.

Die verband tussen die skryfproses en reis word telkens in Hambidge se poësie eksplisiet uitgespel. Die gedig ontstaan as gevolg van die drempelervaring wat reis bied: dit ontstaan uit die spanning van die liminale verhouding tussen 'n verslag van die reis (die reële ervaring) én 'n besinning oor die reis (die innerlike ervaring). Reis word 'n metafoor, maar selfs ook 'n voorvereiste vir die skryf van 'n vers, soos blyk uit die slotstrofe van "Vlugvertraging" (Hambidge, 2000:19):

Die gedig is ' $n$ wagkamer

vol versreëls onrustig

wagtend op die digter:

"Sal alle versreëls

nou aan boord gaan."

Dus: geen vlugvertraging, geen vers.

Daar is in Hambidge se oeuvre ook sprake van 'n reis deur die landskap van die literatuur; ' $n$ reis deur die eie oeuvre, asook deur 
die literatuur van ander skrywers en digters; met ander woorde daar is telkens sprake van intertekstualiteit, of wat Hambidge in 'n verseksterne uitspraak 'n tussentaal noem. In die gedig "By die opruiming van my kantoor" (Hambidge, 2000:48) verwoord sy dit soos volg:

Of is daar geen onbewuste so ooreis, gegrif dié van 'n digter nie net intertekstueel, maar ook letterlik, in transito?

Soos wat die digter op reis gaan, is die omgekeerde ook waar: die gedig gaan self ook op reis. Hambidge (2002b) verduidelik hierdie proses aan die hand van die gedigte wat sy oor New York en spesifiek die gebeure van 11 September 2001 geskryf het. Vanweë die feit dat dié gedigte oorspronklik in Afrikaans geskryf is, reflekteer dit reeds ' $n$ spesifieke ideologie en taal. Omdat dit egter vertaal is, kan dit ook buite die terrein van Afrikaans of Afrikaanse literatuur gelees of verstaan word. Op hierdie wyse reis die gedig dus ook.

Hierdie opvatting word weereens eksplisiet verwoord in die gedig "Vorm en inhoud is nie een nie" (Hambidge, 2002a:57):

Net soos daar'n paar tydsones oorgesteek word deur'n lang internasionale vlug is 'n gedig op reis: tussen aankoms en vertrek; tussen skryf en lees; tussen misverstand en reg begryp; tussen hier en ontsettend ver, daar.

(Kursivering - AN.)

\section{4. "Dat die reëls elders bestaan": die reis as soektog}

Vir die hart se landskap bestaan geen kaart.

In haar intreerede haal Hambidge (2002b) die volgende veelseggende reëls van Rainer Maria Rilke aan waarin hy die doelwit van die reiservaring verwoord, en waarmee sy haar as digter identifiseer:

For the sake of a single verse, one must see many cities, men and things ... One must be able to think back to roads in unknown regions, to unexpected meetings and to partings one had long seen coming ... One must have memories of many nights of love ... 
Die reiskode dien as metafoor vir die ondersoek na betekenisgewing. Cloete (2003:9) wys tereg daarop dat die reisgedigte, 'n belangrike komponent in Ruggespraak, basies soekgedigte is. Hy meen voorts dat die gedig of lied as sodanig 'n soektog is, en die soektog word gedig, soos blyk uit die gedig "Op soek na 'n verlore vers". In "Tankas", die voorlaaste gedig van die bundel, verwys die digter ook spesifiek na "'n reis andersoortig" ... "na plekke waar vervulling / 'n fata morgana bly". Die feit dat vervulling uitbly, word dus by implikasie die stukrag vir die soeke, die reis, die skryf van die gedig.

Hambidge (2002b) wys voorts self ook in 'n verseksterne uitspraak op die soeke in en deur die poësie. Na aanleiding van die uitnodiging om 'n reisrubriek vir Die Burger te skryf, maak sy die volgende uitspraak:

This forced me to re-read my former volumes of poetry which almost always deal with poetry as the ultimate journey, and the specific country or continent becomes the backdrop for a bigger, primordial search. Verdraaide Raaisels - a journey through South America - represents the loss of a relationship and a search for the ultimate truth through the medium of poetry.

Die gedig "Dit het my nog nooit verlaat nie" (Hambidge, 2002a:36) bevestig die opvatting van die reis as soektog. Poëties verwoord Hambidge dit soos volg:

Dit het my nog nooit verlaat nie.

Dit was altyd by my. 'n Paspoort, 'n soort ID van die siel.

Deur elke doeane of kontrolepunt kon ek dit toon: Digter van die hart.

Daar is vele visas toegestaan:

jeugherinneringe, familieskap,

liefdesverse en ander stempels afgedruk.

Die muses maak ruim vergunnings:

nog 'n reis vir liefdesverdriet geëndosseer,

nog'n reis om 'n vroeër self af te sweer,

nog ' $n$ reis om liefdesverraad af te weer,

nog ' $n$ reis om die dood se angel uit te sweer.

Dit mag my nooit verlaat nie.

Dit moet altyd by my bly. Hierdie paspoort, hierdie toegang tot onbereisde streke.

In dié gedig word die verband tussen reis, die liefde en die gedig, sowel as die reis en/of liefde as liminale ervaring weereens bevestig. 
Die paspoort vir die reise word bestempel as die "ID van die siel", en dit toon die spreker se identiteit as "Digter van die hart", en gee "toegang" (dus die drempel as opening) tot die onbereisde streke. Sintaktiese patroonvorming beklemtoon die paspoort as toegangspermit en identiteitsdokument: "Dit het ..." (r. 1), "Dit was ..." (r. 2), "Dit mag ..." (r. 14), "Dit moet ..." (r. 15). Opvallende sintaktiese patroonvorming, die herhaling van die frase "nog 'n reis", sowel as die rymwoorde in versreëls 10-13 dien as uitheffingstegnieke om die rituele aard van die reiservaring, sowel as die dryfvere vir die reise te beklemtoon.

Soos die landskap van die vreemde in talle bundels verken word, word ook die landskap van die liefde verken, en word die soeke met die liefde in verband gebring, soos ook uit die aangehaalde gedig blyk. Hambidge se bemoeienis met die liefde en die geliefde is dwarsdeur haar oeuvre 'n konstante gegewe. Snyman (1998:507) waarsku egter dat die liefdespoësie by Joan Hambidge nie op sigwaarde slegs as liefdespoësie gelees moet word nie. Hy verduidelik voorts:

[D]ie liefdesgedigte by Hambidge betrek die idee van liefde in 'n veel ruimer konteks: dit belig die liefde van vrou tot vrou, dit word beurtelings en afwisselend metafoor en simbool vir en van die wipplank van emosionele wins en verlies, dit belig die verhouding tussen digter en gedig en selfs tussen gedig en leser, dit word die brandpunt vir en van psigiese ontbloting, en dit word die spieël vir die siel waar die gesprek tussen 'n geliefde en 'n gewese geliefde as alter ego's die rasionele en irrasionele komponente van menswees in reliëf bring.

Indien Snyman se argument met die nosie van liminaliteit in verband gebring word, blyk dit duidelik dat die liefde telkens die limen of drempel is waardeur toegang tot die ander of anderkant verkry kan word. Die skryf van gedigte en om lief te hê, is dieselfde liminale belewenis, soos blyk uit "Gedig tussen aanhalingstekens" (Hambidge, 2002:46):

Alles wat ons beleef, is al iewers opgeteken.

Daar is niks nuuts onder die son nie.

' $n$ Gedig het ' $n$ begin, middel en geen einde nie.

Jy en ek is ' $n$ ons, 'n gedig tussen aanhalingstekens

of iets soos kriptomnesia, die erkenning dat die reëls elders

bestaan

[...] 
De Lange (2003:24) maak die geldige stelling dat "die gedig nooit voltooi word nie, net versaak. By Hambidge is dit die geliefde wat telkens versaak word vir die grootste liefde van almal: die poësie. Dis telkens dieselfde gedig wat oorgeskryf word, met "n begin, middel en geen einde'". Dáárom dus is die geliefdes sélf net 'n "gedig tussen aanhalingstekens". Die implikasie is gevolglik dat die liefdeservaring, soos die reiservaring 'n liminale ervaring, 'n telkense tussengebied is. Kriptomnesia is 'n Freudiaanse konsep waarvolgens die geliefde geïnkripteer word op die gees; dat 'n mens as't ware 'n foto van die geliefde in jou onderbewuste saamdra. Volgens die WAT is kriptomnesia "n toestand waarin geheue-inhoude tot die bewussyn kom asof hulle inhoude en oorspronklike skeppings is". Verlies en afwesigheid van die liefde of die geliefde laat egter volgens die aangehaalde gedig die wete "dat die reëls wel elders bestaan". Verlies en afwesigheid is egter onherroeplik ook verbind aan begeerte, en is terselfdertyd die waarborg dat die begeerte sal voortduur. Die volhoubaarheid van begeerte en van die soeke, is dus afhanklik daarvan dat die objek van die begeerte nie verkry word nie, maar dat die afstand behou word. In die slotgedig van die bundel En skielik is dit aand (Hambidge, 2005:158) sluit die digteres die gedig en die bundel af met versreëls wat herinner aan dié van die Nederlandse digter Gerrit Achterberg: "Met hierdie vers / verval alle vorige verse." Hierdie uitspraak gee met ander woorde die mandaat om by herhaling die soeke na die begeerde liefde/ geliefde/gedig opnuut te hervat. Vanweë die feit dat reis/liefde/gedig veel met mekaar in gemeen het, kan die afleiding óók gemaak word dat begeerte 'n konstante dryfveer ook vir die reis is. Hierdie aanname word onderskryf deur Porter, wat begeerte as psigologiese dryfveer wat die reis onderlê, erken:

[M]ost forms of travel at least cater to desire: they seem to promise or allow us to fantasize the satisfaction of drives that for one reason or another is denied us at home. As a result, not only is travel typically fuelled by desire, it also embodies powerful transgressive impulses (Porter, soos aangehaal deur Viljoen, 2003:83).

\section{Reis en ontheemding en kulturele identiteit}

Reis en die verplasing van die self het dikwels ' $n$ gevoel van ontheemding tot gevolg. Viljoen (2003:81) maak die geldige stelling: "Die reis, word daar gesê, is by uitnemendheid daardie soort ervaring wat 'n mens konfronteer met die vreemde en die ander". In die opstel "Questions of travel" beklemtoon Sontag (2003:276) ook die feit dat daar in literatuur oor reis, sedert die klassieke tyd en die 
Middeleeue, klem gelê is op die verhouding "ons" (ek) teenoor "hulle" (die ander). Om te reis impliseer per slot van sake om letterlik en figuurlik 'n grens oor te steek en die ruimte van die ander te betree. Die stelling kan myns insiens egter ook gemaak word, dat om te reis selfs ook beteken om (tydelik) migrant te wees. Soos die migrant, lewe die reisiger op die spanningslyn "tussen hier en ontsettend ver, daar"; "tussen aankoms en vertrek" (Hambidge, 2002a:57).

Die vertrekpunt of oorsprong van die reis veronderstel 'n wegbeweeg van die tuiste of plek van oorsprong. Kearney (1988:14) skryf insiggewend oor die kompleksiteite en paradokse rondom die begrip tuiste (home), en verwys na sommige lerse skrywers as "emigrante van die verbeelding" - 'n stelling wat ook op sommige Afrikaanse skrywers/digters en selfs op die Afrikaner in die algemeen van toepassing is:

It is striking how many modern Irish authors have spoken of being in transit between two worlds, divided between opposing allegiances. They often write as émigrés of the imagination, conveying the feeling of being both part and not part of their culture, of being estranged from the very traditions to which they belong, of being in exile even while at home.

Kearney argumenteer voorts dat die ervaring van in transito te wees, van verplasing en vervreemding, 'n onherroeplike staat is, nie net van die lerse kultuur nie, maar van die hedendaagse wêreldkultuur. Chambers (1994:26-27) onderskryf hierdie stelling as hy beklemtoon dat beweging en migrasie 'n komplekse transformasie tot gevolg het: "The migrant's sense of being rootless, of living between worlds, between a lost past and a non-integrated present, is perhaps the most fitting metaphor of this (post)modern condition." (Kursivering AN.)

Wasserman (2001:302-303) sluit by implikasie aan by hierdie argument as hy wys op die talle openbare debatte in Suid-Afrika oor waarhede aangaande begrippe soos kulturele identiteit of nasie of plek of ontheemding, selfs oor die begrip werklikheid. Wie ons is en waar, en op watter manier ons hoort, is uitdagende vrae waarmee die Afrikaner voortdurend worstel, veral in die era van postapartheid. Bydraend is die beweging van (Suid-)Afrikaners oor die landsgrense heen, wat nou op 'n nuwe manier benoem word, naamlik as "Afrikaner-diaspora". Wasserman maak die voorstel dat diegene wat gebly het "onsself ook kan sien as migrante wat kon ontkom aan die swaartekrag van apartheid Suid-Afrika, en aangekom het in 'n land 
waarin ons onsself moet oriënteer aan die hand van ' $\mathrm{n}$ nuwe kulturele geografie". Hy wys voorts ook daarop dat die migrant (lees ook reisiger/digter; eie invoeging - AN) se herinnering aan herkoms in gesprek begin tree met nuwe impulse, nuwe kulturele geluide wat opgevang en ingeneem word. Die implikasie is dus ook dat daar geen absolute "tuiste" is nie. Wasserman se redenasie korrespondeer met Stuart Hall se opvatting oor kulturele identiteit. Vir Hall (1994:394) is kulturele identiteit

a matter of 'becoming' as well as of 'being'. It belongs to the future as much as to the past. It is not something which already exits, transcending place, time, history and culture. Cultural identities come from somewhere, have histories. But, like everything which is historical, they undergo constant transformation. Far from being eternally fixed in some essentialised past, they are subject to the continuous 'play' of history, culture and power.

In 'n artikel getiteld "No place like Heimat: images of (home)land in European culture" voer Morley en Robins (1993:27) die argument selfs verder en betoog: "Heimat is a mythical bond rooted in a lost past, a past that has already disintegrated." Heimat is met ander woorde ' $n$ utopiese begrip, gefundeer in 'n begeerte na heelheid, eenheid en integriteit. Dit het ook betrekking op gedeelde tradisies en herinneringe. In 'n wêreld wat egter toenemend gekenmerk word deur ballingskap, migrasie en diasporas, en debatte oor die politiek van plek, met gevolge soos hibriditeit, globalisering en ontheemding, is daar dus geen regverdiging vir die verabsolutering van 'n begrip soos Heimat of tuiste nie. Vir Caren Kaplan (1996) is vrae rondom die problematiek van reis onlosmaaklik verbind aan die diskoers van verplasing, soos reeds af te lei is van die titel van haar boek Questions of travel: postmodern discources of displacement. Die klem in die literatuur op reis as ruimtelike verplasing, en die gepaardgaande ontheemding, genereer ook verwysings na terme soos plek, tuiste, grense, kaarte en diasporas, sowel as ballingskap, swerwerslewe en migrasie.

In die reeds aangehaalde intreerede verwoord Hambidge (2002b) haar persoonlike gevoel van vervreemding, wat aansluit by Kearney se argument:

My poetry reflects a sense of displacement. Of writing in a 'tussentaal'. My Afrikaans criticizes the Afrikaans canon. It is packed with English references, slogans, and intertexts. The architecture of my poetry reflects a sense of desolateness/ 
desolation. Of not belonging to Afrikaans literature or its history. It writes against the grain of 'korrekte Afrikaans'.

Poëties verwoord Hambidge (2000:44) dié digterlike aard soos volg:

Die een kant van die Januskop

kyk terug na wat was;

die ander vooruit

na wat woorde kan vermag.

Hierdie uitspraak oor die digterlike identiteit korrespondeer op sý beurt met Hall se opvatting ten opsigte van die migrant (reisiger/ digter) se kulturele identiteit - ' $n$ identiteit gegenereer in die tussengebied van verlede en toekoms.

\section{Die stad as bestemming}

Die bestemming van die talle reise wat deur die digter onderneem word, is meestal wêreldstede. Argitektuur, wolkekrabbers, die uitleg van 'n stad, asook die verkenning en ontdekking daarvan, is aspekte wat onder meer aan die bod kom. Dit is belangrik om in hierdie konteks in gedagte te hou dat die beskrywing van die stad as literêre ruimte nie slegs die blote agtergrond vir die gebeure of handeling is nie, maar dit is dikwels die uiting van opvattings oor sosiale strukture en die lewe in die algemeen. Kortom, daar word meestal in die literatuur doelbewus betekenis aan die stadsgebied toegeken, hetsy positief of negatief. Crang (1998:52) se opvatting in hierdie verband is relevant, as hy daarop wys dat "(the) city is not a two-dimensional mental map ... but a complex multi-dimensional map including the lives, loves and histories of people".

Chambers (1994:92) se kommentaar oor die ervaring van die stad of metropool is veral relevant vir die literatuur in die algemeen, maar kan ook op Hambidge se stadsgedigte van toepassing gemaak word:

The city, the contemporary metropolis, is for many the chosen metaphor for the experience of the modern world. In its everyday details, its mixed histories, languages and cultures, its elaborate evidence of global tendencies and local distinctions, the figure of the city, as both a real and an imaginary place, apparently provides a ready map for reading, interpretation and comprehension.

Vanweë die feit dat die stad 'n gekarteerde ruimte is wat gelees, geïnterpreteer en verstaan kan word, word dit ook ruimtelik-poëties ervaar. Ten opsigte van Hambidge se verse is myns insiens die 
volgende stelling ook geldig: stede word ruimtelik-poëties ervaar, maar stede is self ook gedigte. De Certeau (2000:128) se siening van die stad is in hierdie konteks ter sake. Hy beklemtoon die simbiose van 'n stad as realiteit en die konsep (idee) van 'n stad, dit wil sê die stad as sowel konkrete as verbeelde ruimte. In die artikel The city and the imaginary redeneer Mazzoleni (1993:285) ook dat die stad veel meer is as die materiële konstruksie van geboue, strate en pleine, dit wil sê die sigbare en tasbare gedeelte van habitasie. Agter en in die binneste van die sigbare en tasbare, is ingebed die verbeelde stad of die ruimtelikheid van eksistensie. Die stad as innerlike gebied is moeilik om weer te gee deur middel van woorde of konsepte, omdat dit hoort by 'n prelogiese gebied van belewing, by nie-verbale kommunikasie, of wat Snyman (1998:511) noem die "primordiale wêreld" (vgl. punt 1). Daar is wel 'n osmotiese wisseling tussen die innerlike en uiterlike belewing van die stad as ruimte. In 'n ander konteks stip Hambidge aan wat sy bestempel as "n bloudruk vir alle reiservaringe", naamlik "wat 'n mens dink jy weet van 'n land, wat jy uiteindelik ervaar, en wat jy nooit werklik sal kan begryp of dekodeer nie". Dít wat met ander woorde nie begryp of gedekodeer kan word nie, kan dus ook nie volledig verwoord of verdig word nie.

Sowel De Certeau as Mazzoleni se idees kan op Hambidge se stadsgedigte van toepassing gemaak word, want die wisselwerking tussen woord en wêreld, tussen innerlike belewing en die woord, word telkens in die gedig verken. In "Memorial day: New York 25/5/2000" (Hambidge, 2002a:55) word die stad as tekstuele én werklike (referensiële) verwysing, sowel as idee voorgehou. In die gedig word die stad nie alleen eksplisiet gelykgestel aan die gedig nie, maar die belewing van die stad word ook metafoor vir die poësie-konsepsie. Uit die onbewuste, dus innerlike belewing van die stad, sowel as 'n sterk sintuiglike bewustheid, ontstaan die gedig.

\section{Memorial day: New York 25/5/2000}

Gedenk die einde van die oorlog want dit gee lewe aan die poësie!

New York self is 'n grootse gedig vol teenstrydighede soos dat'n bestemming op Wes iets anders beteken as dieselfde adres op Oos; dat die gedig sy uitskot in Soho en Bowery uitwerp as oortollig, onnodig, onaansienlik; boonop dat die subway die onbewuste, nooit gesêde is soos 'n gedig spreek dít aan wat onherstelbaar of verganklik is; dat iewers in al hierdie teenstrydighede tekens 
daar 'n rusplek soos Central Park is die kern of hart van die gedig (ek sal jou nooit vergeef of kan vergeet); dit begin met 'n opslag- of toevalsreël soos "'n stad besluit oor die roete vir 'n reisiger". Die ritme soos 'n jazz-weergawe van "start spreading the news" bedui dat die digter die eerste weergawe moet ken. Dan die metrum en die wete dat'n grootse gedig hom nie eenvoudig laat skandeer. Dit dra immers die hele wêreld in die palm van sy hand. Teen die NY skyline sy tuimelende tweelingtorings ...

'n Vloed van indrukke oorval die digter. Soek na 'n holte vir die voet. In die hotel Prosody grendel die digter haar onbewuste teen 'n gedig wat broei uit bloedsweet.

In Hambidge se reeds genoemde reisrubriek haal sy die volgende reëls van Wallace Stevens aan: "Life is an affair of people not of places. But for me life is an affair of places and that is the trouble". Sy bevestig ook ten slotte: "Ek moet Stevens gelyk gee: die grootste verhoudings is met stede" (Hambidge, 2004a:3). Hambidge (2002c:12) bely in 'n ander uitspraak dat New York een van haar allergunsteling stede is. Sy beklemtoon voorts ook die feit dat New York 'n mitiese stad is, wat as't ware die hele wêreld in hom saamvat. Pike (1981:8) skryf op sy beurt insiggewend oor die mite van die stad, en sy opvattings kan ter toeligting met Hambidge se uitspraak in verband gebring word. Die bifokale blik op die werklike én die mitiese stad kan verklaar word vanuit die feit dat alle mites pogings is om sekere realiteite te verklaar. Basiese oorgelewerde mites is in wese pogings om rekenskap te gee van sekere natuurverskynsels en -gebeure. Die mite van die stad, daarenteen, moet poog om 'n objek te rasionaliseer wat deur die mens tot stand gebring is, en wat as gevolg van sy grootte en konsentraat van ritueel en mag (religieus, staat, militêr, finansieel), die natuur in die natuurlike wêreld vervang het. Die visuele panorama van die stad met sy strate, sy geboue en sy wolkekrabbers, sowel as die kinetiese energie van sy bewoners is waarskynlik by uitstek die mens se mees imponerende argitektoniese en visuele prestasie. Barthes (1982:160) wys ook in 'n ander konteks op die slim geometriese uitleg van New York se strate, wat die mens in staat stel om afstand en oriëntasie toe te eien. "This is the purpose of New York's geometry: that each individual should be poetically the owner of the capital of the world" (kursivering - R. Barthes). 
Hambidge verwoord bogenoemde opvattings poëties soos volg in die eerste drie strofes van die gedig "New York" (Hambidge, 1985:43):

\author{
Geëerde geagte \\ nooit volprese veel besonge stad \\ van menige mites \\ in jou onherbergsame kakofoniese vuis \\ het ek'n maand vertoef
}
verwonderd (eers bevrees) oor jou hemelhoë
strekkende vingers
tot waar die oog
net 'n stippel sien van toppe

deurkruis dan jou simmetriese palm

vind links en regs

is hier gelyk (dus oos op wes)

met Hudson en East

jou duim 'n nimlike trotse marmervrou

hand in die lug die vertes in

jou kneukelhand is ook ' $\mathrm{n}$ hel (as ons na patrone kyk)

In albei aangehaalde gedigte oor New York blyk duidelik die digterspreker se persoonlik interaksie met dié stad. Enersyds word daar aan die stad menslike eienskappe toegedig, maar die emosies wat die spreker ervaar is op paradoksale wyse ook dié van begeerte en vrees. In 'n poëtiese essay getiteld "Milton Friedman's smile: travel culture and the poetics of a city", skryf Osborne (1993:331) inleidend soos volg: "Wandering and travelling appear driven by transgression and lack, that is, by fear and desire - fear and desire drawn by the attraction of cities." Ook Robins (1993:326) skryf insiggewend oor die aard van die hedendaagse stedelike flâneur as simboliese figuur van die nuwe stedelike droom. Hy lê voorts 'n verband met die gevoelige ingesteldheid van die Duitse Ekspressionistiese poësie, wat 'n soortgelyke figuur oproep, vasgevang in die kompleksiteit - die gevare én die opwinding - van die stad. Anders as die tradisionele flâneur, is hierdie figuur nie langer slegs ' $n$ passiewe ontvanger van indrukke nie. Sy/haar verbeelding bring die poëtiese diskoers in beweging in 'n samevattende ordening van indrukke, wat 'n onderliggende bewuswees van spanning, bedreiging en konflik weergee. Hierdie figuur vind geen toevlug in 'n esoteriese bepeinsing nie, maar word voortdurend gekonfronteer met die stedelike opwinding en onrus waarmee hy/sy deurentyd uitgedaag word. 
In 'n essay oor New York wys Hambidge (2002c:12) daarop dat New York 'n stad vol paradokse is en dat vrees argetipies deel van dié stad is. Dit is trouens juis New York se negatiewe aspekte wat aan hom ikoonstatus verleen het deur al die jare. Vrees en die stad het egter deur die eeue alles met mekaar in gemeen. Pike (1981:4) skryf weereens insiggewend in hierdie verband. In die geskiedenis van die Westerse kultuur is die stad herhaaldelik as retoriese topos gebruik. Die mens se toe-eiening en beheersing van sy omgewing verhul egter ook 'n ander aspek, naamlik 'n diepgewortelde angs ten opsigte van die mens se verhouding met sy geskape wêreld. Die stad kristalliseer daardie bewustelike en onderbewustelike spanning wat van die begin af die stad in die Westerse kultuur karakteriseer. Dit is hierdie kristallisering wat die mens se preokkupasie met die stad verklaar, of die byna hipnotiese aantrekkingskrag vir sy vernietiging sedert Troje, Sodom en Gomorra, en Kartago verantwoord.

Vir die stad New York, vir sy inwoners sowel as sy besoekers, het hierdie onderliggende vrees waar geword met die gebeure van 11 September 2001. Baudrillard (2002:59) som inderdaad die kollektiewe ervaring raak op as hy sê: "So, at Ground Zero, in the rubble of global power, we can only, despairingly, find our own image". Die digterlike interpretasie van dié gebeure verwoord Hambidge (2002a:68-69) in die gedig "Start spreading the news":

So kom jou Oordeelsdag, New York

'n dag waarop jy geweeg en te swaar bevind

is deur jou eie reputasie, jou oopgesteldheid,

jou onopgesmukte groter as lewensgroot dáár wees,

veral jou hubris: New York is die hele wêreld in een dag.

Miskien sou jy die meeste wens

dat jy hulle wat in jou hart was, kon beskerm

teen die vlammehel, die toorn van só 'n dag.

Kon jy hul angs registreer? Daardie paartjie wat hand aan hand

uitspring? Hul cul de sac voel tussen vuur en vuur?

In die ontroerende gedig "Ground zero" wend Hambidge (2002a:71) op ironiese wyse die reismetafoor aan om die lewensvernietiging in digterlike terme te beskryf:

Hierdie reisigers had nie nodig

om ' $n$ tas te pak,

'n visum te verleng,

of deur 'n doeanegebou te stap. 
Daar is geen jet lag

of frustrasies met' $n$ vreemde taal, wisselkoers, of vreemd slaap.

Want die vliegtuig het geland voor hul ongevraagde vertrek.

\section{Ten slotte}

In hierdie artikel is enkele geselekteerde reisverse in Joan Hambidge se bundels Lykdigte en Ruggespraak ondersoek, sowel as die verband tussen die reiservaring en liminaliteit. Volgens die getuienis van hierdie gedigte, is die reis as liminale ervaring of tussentoestand enersyds 'n proses wat by uitstek geskik is om die persoonlike en digterlike identiteit te verken, 'n ondersoek na betekenisgewing te loods, en tot 'n (her)ontdekking van die self te kom deur middel van die digterlike woord. Andersyds ontstaan die gedigte juis uit dié reiservarings, en gevolglik toon talle gedigte ook liminale eienskappe en word liminale beelde gebruik om die temas van reis, die liefde en die digproses te beskryf. Hambidge se reisgedigte bevestig voorts ook haar volgehoue bemoeienis met populêre kultuur en die aktualiteit van die dag, soos blyk uit die stadsgedigte oor New York.

\section{Geraadpleegde bronne}

AGUIRRE, M., QUANCE, R. \& SUTTON, P. 2000. Margins and thresholds: an enquiry into the concept of liminality in text studies. Madrid: The Gateway.

BARTHES, R. 1982. Buffet finishes off New York. (In Sontag, S., ed. A Roland Barthes reader. London: Vintage. p. 158-161.)

BAUDRILLARD, J. 2002. The spirit of terrorism and other essays. (Translated by Chris Turner.) London: Verso.

CHAMBERS, I. 1990. Border dialogues: journeys in postmodernity. London: Routledge.

CHAMBERS, I. 1994. Migrancy, culture, identity. London: Routledge.

CLIFFORD, J. 1989. Notes on travel and theory. Inscriptions, 5:177-188.

CLIFFORD, J. 1992. Traveling cultures. (In Grossberg, L., Nelson, C. \& Treichler, P.A., eds. Cultural studies. London: Routledge. p. 96-116.)

CLOETE, T.T. 2003. "Ruggespraak" groot verfynde vlegwerk. Beeld: 9, 13 Jan.

CRANG, M. 1998. Cultural geography. London: Routledge.

CROUS, M. 2000. Weer interne verhuising vir Hambidge. Die Burger: 8, 16 Aug.

DE CERTEAU, M. 2000. Walking in the city. (In During, S., ed. The cultural studies reader. London: Routledge. p. 126-133.)

DE LANGE, J. 2003. In dié verse hoor jy Auden saggies lag. Rapport: 14, 6 April. 
HALL, S. 1994. Cultural identity and diaspora. (In Hall, S. Colonial discource and post-colonial theory: a reader. New York: Columbia University Press. p. 392-403.)

HAMBIDGE, J. 1985. Hartskrif. Kaapstad: Human \& Rousseau.

HAMBIDGE, J. 1988. Geslote baan. Kaapstad: Tafelberg.

HAMBIDGE, J. 2000. Lykdigte. Kaapstad: Tafelberg.

HAMBIDGE, J. 2002a. Ruggespraak. Pretoria: Protea Boekhuis.

HAMBIDGE, J. 2002b. Whose inaugural is it anyway? Modern criticism in crises. Kaapstad. (Ongepubliseerde manuskrip.)

HAMBIDGE, J. 2002c. NY: hele wêreld in stad vol paradokse. Die Burger: 12, 14 Sept.

HAMBIDGE, J. 2004a. Verhoudings met stede is groots. Die Burger. 3, 28 Feb.

HAMBIDGE, J. 2004b. Desperately seeking Susan Sontag: 'n essay-verhaal. http://www.litnet.co.za/seminaar/jhsont.asp Datum van gebruik: 5 Julie 2005.

HAMBIDGE, J. 2005. En skielik is dit aand. Pretoria: Protea Boekhuis.

HAUPTFLEISCH, D.C. 1991. Woordeboek van die Afrikaanse Taal. Deel VIII. Stellenbosch: Buro van die WAT.

KAPLAN, C. 1996. Questions of travel: postmodern discourses of displacement. Durham: Duke University Press.

KEARNEY, R. 1988. Transitions: narratives in modern Irish culture. Dublin: Wolfhound.

KICKASOLA, J.G. 2004. The films of Krzysztof Kieslowski: the liminal image. New York: Continuum.

MAZZOLENI, D. 1993. The city and the imaginary. (In Carter, E., Donald, J. \& Squires, J., eds. Space and place: theories of identity and location. London: Lawrence \& Wishart. p. 285-302.)

MORLEY, D. \& ROBINS, K. 1993. No place like Heimat: images of home(land) in European culture. (In Carter, E., Donald, J. \& Squires, J., eds. Space and place: theories of identity and location. London: Lawrence \& Wishart. p. 3-32.)

OSBORNE, P. 1993. Milton Friedman's smile: travel culture and the poetics of a city. (In Carter, E., Donald, J. \& Squires, J., eds. Space and place: theories of identity and location. London: Lawrence \& Wishart. p. 331356.)

PIKE, B. 1981. The image of the city in modern literature. Princeton: Princeton University Press.

RETIEF, H. 2003. Die gevaarlike lewe van 'n digter. Rapport: 25, 26 Jan.

ROBINS, K. 1993. Prisoners of the city: whatever could a postmodern city be? (In Carter, E., Donald, J. \& Squires, J., eds. Space and place: theories of identity and location. London: Lawrence \& Wishart. p. 303-330.)

SAID, E. 1983. Traveling theory. (In Said, E. The world, the text and the critic. London: Vintage. p. 226-247.)

SMITH, K. 2004. The emptiness of zero: representations of loss, absence, anxiety and desire in the late twentieth century. Critical Quarterly, 26(1): 40-59.

SNYMAN, H. 1998. Joan Hambidge. (In Van Coller, H.P., red. Perspektief en profiel. Pretoria: Van Schaik. p. 503-513.)

SONTAG, S. 2003. Where the stress falls. London: Vintage.

VAN DEN AKKER, W. 1985. Een dichter schreit niet: de poetica van M. Nijhoff: aspecten van M. Nijhoffs versexterne poetica. Utrecht: Veen. 
VILJOEN, L. 2003. Die digter as reisiger: twee gedigsiklusse van Leipold en Krog. Stilet, 15(1):80-100.

WASSERMAN, H. 2001. Om hergeboorte te verbeel. (In Van Heerden, E., red. Briewe deur die lug. LitNet-skrywersberaad 2000. Kaapstad: Tafelberg p. 297-308.)

WAT

kyk HAUPTFLEISCH, D.C.

Kernbegrippe:

Hambidge, Joan

liminaliteit en reis

reisverse

stadsgedigte

Key concepts:

Hambidge, Joan

liminality and travel

travel poetry

urban poetry 